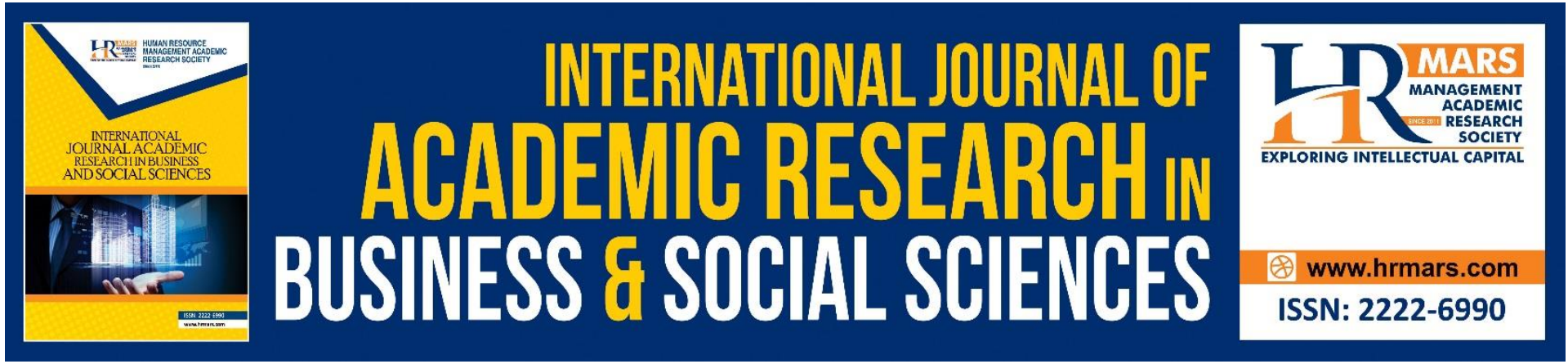

\title{
Relationship Between Spiritual Practice and Psychological Well-Being During Pandemic Covid-19 among Muslim in Selangor
}

\author{
Siti Mariam, Noraini Saro
}

To Link this Article: http://dx.doi.org/10.6007/IJARBSS/v11-i9/10884

DOI:10.6007/IJARBSS/v11-i9/10884

Received: 08 July 2021, Revised: 29 July 2021, Accepted: 18 August 2021

Published Online: 02 September 2021

In-Text Citation: (Mariam \& Saro, 2021)

To Cite this Article: Mariam, S., \& Saro, N. (2021). Relationship Between Spiritual Practice and Psychological Well-Being During Pandemic Covid-19 among Muslim in Selangor. International Journal of Academic Research in Business and Social Sciences, 11(9), 605-612.

Copyright: (c) 2021 The Author(s)

Published by Human Resource Management Academic Research Society (www.hrmars.com)

This article is published under the Creative Commons Attribution (CC BY 4.0) license. Anyone may reproduce, distribute, translate and create derivative works of this article (for both commercial and non-commercial purposes), subject to full attribution to the original publication and authors. The full terms of this license may be seen at: http://creativecommons.org/licences/by/4.0/legalcode

Vol. 11, No. 9, 2021, Pg. 605 - 612

http://hrmars.com/index.php/pages/detail/IJARBSS

JOURNAL HOMEPAGE

Full Terms \& Conditions of access and use can be found at http://hrmars.com/index.php/pages/detail/publication-ethics 


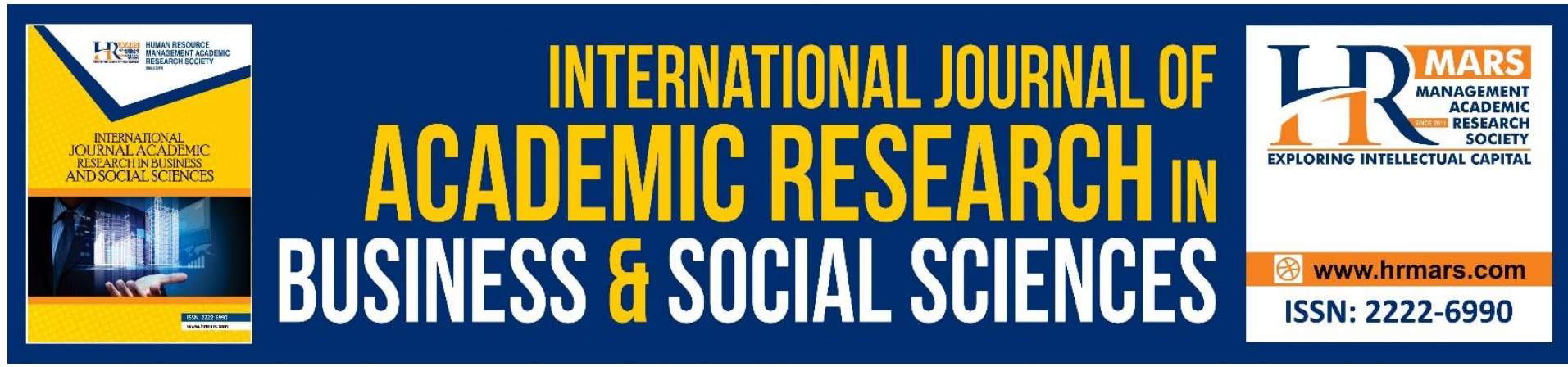

\title{
Relationship Between Spiritual Practice and Psychological Well-Being During Pandemic Covid-19 among Muslim in Selangor
}

\author{
Siti Mariam \\ Center for Islami Philantropy and Social Finance, Faculty of Business Management \\ University Teknologi MARA, Cawangan Melaka,KM 26, Jalan Lendu, 78000, Alor Gajah, \\ Melaka. \\ Email.smali@uitm.edu.my \\ Noraini Saro \\ Faculty of Academic Islamic Studies Contemporary Universiti Teknologi MARA, Cawangan \\ Shah Alam Selangor. \\ Email : ainisaro175@gmail.com
}

\begin{abstract}
This study aims to observe the correlation between spiritual practice and psychological well being, during pandemic covid-19. The tools used for measuring spiritual practice, The inventory that have been used are Inventory Internal Religiosity (IIR) which is to measure the religiosity while the Ryff Sclaes of Psychological Well-Being (RPWB) is used to measure the Psychological Well-Being. The overall mean indicates that the spiritual practices practiced by the Muslim community in Selangor during the transmission of the covid pandemic -19 are at a high level with a mean value $=3.81$. The relationship between spiritual practice and psychological well-being shows that this hypothesis is clearly answered and it is acceptable that there is a high relationship with the reading value of $r$ is $(r=1.00)$ and significance with value ( $p \leq 0.05)$. The spread of the covid-19 Pandemic that hit the world had an impact on the level of human psychological well-being around the world. However, as a Muslim, he has a strong spiritual 'defense' by multiplying prayers to Allah SWT to be given protection, thus avoiding dangerous diseases.
\end{abstract}

Keywords: Spiritual Practice, Psychological well-being, Pandemic Covid-19, Muslim Selangor

\section{Introduction}

According to Director-General of Health Tan Sri Dr Noor Hisham Abdullah, Malaysia has now entered the third wave of the pandemic covid-19. At the time of writing, 23 November 2020, the number of COVID-19 cases in Malaysian has reached 56,659 cases and recorded 337. Of the 13,842 active cases, 115 the case is of critical status. In Malaysia, the Movement Control Order (MCO) was implemented on the $18^{\text {th }}$ March 2020 (Utusan, 2020). Besides that, according, (Zolkepli, 2020) he said anyone can be affected emotionally during an outbreak like COVID-19 and also reacts differently to critical scenarios. 
Latifah in her daily news report stated that among the good practices to be practiced when facing the COVID-19 epidemic is to seek protection from Allah SWT by reading Ratib al-Attas as has been informed by Muhadir. "Ratib Al-Attas is a reading practice that contains verses from the Quran, hadith of the Prophet SAW, remembrance and prayers compiled by Al-Habib Umar Abdul Rahman al-Attas. In addition, by reading Ratib al-Attas, the faith becomes more robust provided that the content and purpose of reading it must be understood (Ibrahim, 2020)

The spread of the covid -19 pandemic around the world is now making society start life with a new norm. Living this new norm is one way to prevent the spread of this epidemic.The Ministry of Health Malaysia (MOH), has issued preventive measures. As a Muslim it is advised to strive through daily prayers and practices. The words of Allah SWT in Surah al-Baqarah verse 153 which means "O you who believe! Ask for help (to Allah) with patience and prayer. Indeed, Allah and the people are patient.

\section{Objective}

This study is to study the relationship between and psychological well-being during pandemic covid-19 among Muslim in Selangor.

Meanwhile, the objectives in particular are;

i. To identify the spiritual practices practiced by the Muslim community in Selangor

ii. To identify the level of psychological well-being of the Muslim community in Selangor during the transmission of the covid-19 pandemic.

iii. To analyze the relationship between spiritual practice and the psychological wellbeing of the Selangor Muslim community during the transmission of the covid-19 pandemic.

\section{Literature Review \\ Overview of Psychological well-being during Pandemic Covid-19}

Psychological well-being is something that is multidimensional in nature and is defined in various forms (Hupert \& So, 2013; Diener et al., 2010). Although in general, there is no single definition, there is a general consensus among scholars that psychologically prosperous individuals should have positive moods and emotions (e.g. happy, happy, enthusiastic); low negative emotions (e.g. fear, anxiety); satisfied with his quality of life (general; specific such as employment; family); and function positively (have autonomy; meaning and purpose of life)

According to (Roslan, 2020) early half a million people in the country suffer from depression based on the statistics of the National Health and Morbidity Survey (NHMS) conducted in 2019. Statistics include 2.3 percent of the people in this country aged 16 years and above have mental health. The spread of Covid-19 has a huge impact on the world community, including Malaysia. Most people are affected by emotions such as anxiety, fear, isolation, uncertainty and emotional stress due to changes in life norms. According to (Muharam, 2020) Employees who are on leave and lose their jobs are believed to be experiencing severe mental well-being during the Movement Control Order (PKP) period. Based on the survey conducted by the research organization, The Center against 720 out of 1084 respondents nationwide with the majority being in the Klang Valley during the third week of PKP. The results showed that 39 to 54 percent of respondents admitted to experiencing emotional disorders as a result of salary reduction. 


\section{Religious Elements in the well-being of Life}

According to (Wahid, 2010) the influence of religious elements is often associated as one of the factors that affect well-being the life of an individual, a community or a nation. In his study has discussed the influence of religious factors on the quality of life of individuals. According to them, the religious factor is important because it affects mental health, changing an individual's attitude towards a life positive that will ultimately change the economy and lifestyle of the individual in the long run.

While in the study written by (Sodiq, 2015)is about the concept of well-being in Islam. According to researchers, in Islam, the well-being of life is given by Allah s.w.t. to anyone (men or women) who want to do good deeds and accompanied by faith in Gods.w.t. The researcher also stated that the three indicators to measure the well-being of life and happiness are mental formation (monotheism), use and loss of fear and all forms of anxiety other than to Allah s.w.t.

The aim of this methodologically qualitative study was to explore among Muslim in Selangor on psychological well-being during pandemic Covid-19. A sample of 80 participants was collected from Muslim's Community in Puchong, Selangor. Convenience sampling procedure was used. The study was conducted in Puchong, Selangor. Convenience sampling procedure was used. Multi-dimensional measure of Islamic spirituality was used to measure Islamic spirituality. This questionnaire designed to describe the Muslim's demographic information, such as gender, occupation, age. Psychological Well-Being Scales: (Ryff's, 1989a) scale of PWB contains six dimensions: self-acceptance, personal growth, purpose in life, positive relations with others, environmental mastery, and autonomy. Data Analysis Data was analyzed using SPSS version 21.0 .

\section{Result \& Discussion \\ Demographic of Respondent}

In this study the starting point to be discussed is part A which is the demographic of the respondents. There are five items that will be discussed, namely, gender, age, marital status, occupation and level of education. The first finding is the breakdown of the number of respondents by gender.. The results of the study found that male respondents were 41 people $(51.3 \%)$, while female respondents were 39 people (48.8\%). Next is group of age a total of 27 people (33.8\%) of the study respondents were aged 20 to 30 , a total of 42 people $(52.5 \%)$ aged between 31- 40 years, a total of 11 people (13.8\%) aged between 41 years to 50 years. While the second is the breakdown according to the age of the respondent. The results of the study found a total of 28 people (35.0\%) of the study respondents are single, a total of 46 people $(57.5 \%)$ are married and 6 person $(7.5 \%)$ consists of divorce. Meanwhile, for the level of education, there are 18 (22.5\%) Muslims educated at the SPM level, for the STPM / Diploma category, there are $43(53.8 \%)$ people. Next, a total of $15(18.8 \%)$ people are educated at the degree level and a total of $4(5.0 \%)$ people are educated at the master's level. The last demographic is related to the job of the respondent. A total of $12(15 \%)$ respondents work in the public sector. While for the private sector is a total of 38 people $(47.5 \%)$. Next, a total of $10(12.5 \%)$ self-employed people and a total of 20 (25\% ) others. 
Table 1.1 Descriptive Statistics religiousity practice

\begin{tabular}{|l|r|r|}
\hline & N & \multicolumn{1}{|c|}{ Mean } \\
\hline I read the Quran & 80 & 3.68 \\
I set up prayers in congregation & 80 & 3.56 \\
I immediately beristigfar if restless & 80 & 3.94 \\
I believe God is just & 80 & 4.61 \\
I perform circumcision fasting & 80 & 3.60 \\
I give help to those in need & 80 & 4.70 \\
I recite zikir after the prayer & 80 & 4.33 \\
I did not leave the prayer & 80 & 3.64 \\
I have never been grateful & 80 & 1.85 \\
I am under the command of Allah SWT & 80 & 4.55 \\
I always try to improve my religious knowledge & 80 & 4.39 \\
I read the Quran fluently & 80 & 4.06 \\
I understand the teachings of religion well & 80 & 3.45 \\
I easily ignore God's commands & 80 & 3.09 \\
I pray fervently. & 80 & 3.74 \\
& 80 & 3.81 \\
& & \\
\hline
\end{tabular}

Table 1.1 shows the value of the frequency of spiritual practices practiced by the Muslim community in Selangor. The item with the highest mean score is item 6, i provide assistance to those in need. ( $\mathrm{min}=4.70)$. Meanwhile, the second highest item is item 4 which I believe God is just with a mean $=4.61$. The item with the lowest mean score is the item that by me I have never been thankful with a mean $=1.85$. The overall mean indicates that the spiritual practices practiced by the Muslim community in Selangor during the transmission of the covid pandemic -19 are at a high level with a mean value $=3.81$.

According table 1.2 the frequency values of the level of well-being of the Muslim community in Selangor during the transmission of the Covid-19 Pandemic. The item with the highest mean score is item 1 i.e. I always take wisdom with what happens (mean $=4.63$ ). Meanwhile, the second highest item is item 11 which is that I make the best use of movement control command time. With mean $=4.53$. The item with the lowest mean score is item 9 which I think God is not fair because he gave me a heavier test compared to others with a mean = 1.63. The overall mean shows that the psychological well-being practiced by the Muslim community in Selangor during the transmission of the covid pandemic -19 at a moderate level with a mean value $=3.34$.

Based on these two tables show the Muslim community in Selangor doing good spiritual practices throughout the transmission of the covid-19 pandemic. The spiritual practices practiced by the Muslim community have affected their psychological well-being throughout the spread of the covid-19 pandemic. This spiritual practice also helps them cope with the contagion of the covid 19 pandemic more calmly, despite the fact that the world is being plagued by dangerous epidemics. 
Table 1.2 Descriptive Statistics psychology well- being

\begin{tabular}{|l|r|r|}
\hline & N & Mean \\
\hline I always take wisdom with what happens. & 80 & 3.50 \\
I always feel anxious facing the covid -19 pandemic & 80 & 4.51 \\
I am grateful for what I have. & 80 & 3.31 \\
I am always restless when thinking about the future with covid-19 & 80 & 1.75 \\
transmission & 80 & 2.30 \\
The spread of pandemics made me a negative person & 80 & 3.66 \\
I always feel anxious when announcements related to the covid-19 & 80 & 2.70 \\
pandemic & 80 & 1.63 \\
I always try something new, especially when the control order is & 80 & 1.73 \\
executed & 80 & 4.53 \\
I was also nervous when I saw other people being nervous during the & 80 & 4.45 \\
covid-19 pandemic & 80 & 4.50 \\
I think God is not fair because he gave me a heavier test than anyone & 80 & 2.59 \\
else & 80 & 4.44 \\
I lost direction when the covid-19 pandemic spread around the world & & \\
I make the most of the movement control command time & & \\
I was prepared for the life to come after the pandemic & \\
I know of the potential it has for coping with the covid-19 pandemic & & \\
I find it difficult to accept the spread of the covid-19 pandemic in & & \\
Malaysia & & \\
I always learn with the current situation & $\mathbf{3 0}$ & $\mathbf{3 . 3 4}$ \\
\hline Total &
\end{tabular}

Table 1.3 Correlations

\begin{tabular}{|ll|r|r|}
\hline & & \multicolumn{1}{|c|}{$\begin{array}{c}\text { Spiritual } \\
\text { Practice }\end{array}$} & $\begin{array}{r}\text { Psychological Well- } \\
\text { Being }\end{array}$ \\
\hline Spiritual & Pearson & 1 & $1.000^{* *}$ \\
Practice & Sig. (2-tailed) & & \\
& $\mathrm{N}$ & 80 & .000 \\
& Pearson & $1.000^{* *}$ & 80 \\
Psychologi & Correlation & & 1 \\
cal & Sig. (2-tailed) & .000 & \\
& $\mathrm{~N}$ & 80 & 80 \\
\hline
\end{tabular}

**. Correlation is significant at the 0.01 level (2-tailed).

Based on table 1.3, the results of this analysis show that there is a relationship between spiritual practice and the level of psychological well-being among the Muslim community in Selangor. The relationship between spiritual practice and psychological well-being shows that this hypothesis is clearly answered and it is acceptable that there is a high relationship with the reading value of $r$ is $(r=1.00)$ and significance with value $(p \leq 0.05)$. This means that the spiritual practice practiced by the Muslim community is able to provide good psychological well-being throughout the covid-19 pandemic transmission. 


\section{Conclusion}

The spread of the covid-19 Pandemic that hit the world had an impact on the level of human psychological well-being around the world. The situation is seen to be increasingly annoying for the government to officially declare a Movement Control Order (PKP) to restrict the movement of the public to choose the spread of the epidemic.This situation also creates an impact on the psychology of society and individuals.

Psychological studies from previous pandemics such as Severe Acute Respiratory Syndrome (SARS) found that the period of PKP or quarantine throughout the pandemic period had a significant relationship with psychological issues such as emotional stress. Psychologically, individuals are likely to encounter negative thought patterns that can affect their emotions throughout the implementation of PKP. Moreover, anxiety, sadness and uncertainty, are of course interpreted differently for each individual as each has its own challenges and responsibilities to face. However, as a Muslim, he has a strong spiritual 'defense' by multiplying prayers to Allah SWT to be given protection, thus avoiding dangerous diseases. As a believing Muslim we will be able to face this test with patience and realize our weaknesses and self-loathing. Various approaches to spiritual practice that we can do either alone or with our families.

This paper also suggests that, society is able to cope with emotional stress, by engaging in activities that can alert the mind from negative emotions. In addition, it is encouraged for each individual to use mind training techniques to assess frustration from a different perspective. Among them are trying to remove depressed emotions such as feeling frustrated or bored by watching funny movies, reading motivational books and doing craft activities that can shift thoughts in a positive and more creative direction. Increasing focus on positive things to enjoy inner peace is also an effective mind -shifting technique.

In addition to health care, healthy eating and adequate sleep are important factors to help maintain stable emotions, creating a relaxing time for emotional expression with family members is also the best technique to get rid of sad and tired emotions. This technique can help maintain healthy relationships as well as build a strong support system with family members. Overall, emotional stability in dealing with this Covid-19 crisis is important to ensure that each individual goes through a daily routine without any stress.

\section{Acknowledgement}

The authors would like to extend their gratitude to University Teknologi Mara (UiTM) Melaka for funding the researcher through TEJA GRANT (GDT2020-39) for the year 2020.

\section{Reference}

Ibrahim, L. (2020). Ratib al-Attas, 'jihad' rohani hadapi COVID-19. From Berita Harian: https://www.bharian.com.my/rencana/agama/2020/04/672617/ratib-al-attas-jihadrohani-hadapi-covid-19

Muharam, R. (2020). PKP beri kesan kesejahteraan mental. From Metro https://www.hmetro.com.my/mutakhir/2020/05/578740/pkp-beri-kesankesejahteraan-mental

Roslan, S. (2020). Hampir 0.5 juta warga Malaysia kemurungan. Kuala Lumpur . https://www.hmetro.com.my/utama/2020/10/629299/hampir-05-juta-wargamalaysia-kemurungan 
Ryff, C. D. (1989a). Happiness is everything, or is it? Explorations on the meaning of psychological well-being. Journal of Personality and Social Psychology, 57, 6, 10691081

Sodiq, A. (2015). Konsep Kesejahteraan dalam Islam. Journal Ekonomi Syariah. EQUILIBRIUM, Vol. 3, No. 2. Hal. 380-405., 380-405.

Utusan. (2020, 10 9). From https://www.utusanborneo.com.my/2020/10/09/malaysia-kinimemasuki-gelombang-ketiga-pandemik-covid-19

Wahid, H. (2010). Hairunnizam Wahid et. al. (2010). Pengaruh Faktor Keagamaan Terhadap Kualiti Hidup Individu : Kajian Kes Asnaf Fakir dan Miskin. Kertas seminar ini dibentangkan di Seminar Kebangsaan MACFEA ke-14: Hala tuju Penyelidikan Kepenggunaan. . Seminar Kebangsaan MACFEA ke-14.

Zolkepli, F. (2020, 3 28). The Star. From https://www.thestar.com.my/news/nation/2020/03/28/covid-19-pui-found-dead-inserdang-hospital-toilet-suicide-suspected 